\title{
SOCIO-CULTURAL VALUES AS COMMUNITY LOCAL WISDOM KATOBA MUNA IN THE DEVELOPMENT OF LEARNING MATERIALS SOCIAL STUDIES AND HISTORY
}

\author{
Laode Monto Bauto ${ }^{1}$
}

\begin{abstract}
Katoba culture as one form of local wisdom Muna society contains many positive values that need to be preserved and developed. The positive values include the religious, social, political, economic, and historical values. This study addressed the relating socio-cultural values learning with appropriate conceptual of Social Science for Elementary school curriculum. Because one of the goals of this study is to develop learning materials Social Science- Elementary school to enhance the knowledge, attitudes and skill students against local culture (Katoba) in effort to mastery the subject matter of Social Science- Elementary school. Therefore, in the development learning materials will be integrated with relevant local cultural values. The relevant local cultural values (Katoba) curriculum of Social Science-Elementary school is the social values, culture, economics, politics/history and art/creativity and religion. In addition, the integration of social values in learning katoba cultural, Social Science through cooperative approaches with clarification in terms of the value of learning according to permendiknas No. 41/2007-th model is relevant to theories of learning and the learning model is selected. Through the stages of Social Science learning model development that are expected to improve the results of the study (koginitif), strengthen the appreciation and attitude of the students towards the local culture (katoba). This emphasis on the process of the learners how to learn through reconstruction, find, acquire knowledge and develop social values of cultural katoba, that is believed or understood and served as a pattern of behaviour guidelines in social life. The learning process is in line with the emphasis on the ideal character education of self-reliance human (moral autonomy) in a neighbourhood, community, nation, and state.
\end{abstract}

Key words: Cultural Values, Local Wisdom, social studies learning, history learning

\section{Introduction}

Indonesia has potential local culture that boasted of having diversity and varied considerably and has its own uniqueness. However, over the growing period that gave reason to the change pattern of more modern life society, people prefer the new culture that may be judged more practical than local culture. There are many factors that cause local culture is forgotten now, one of them due to the influx of foreign culture. In reality, foreign culture tends to dominate,

\footnotetext{
${ }^{1}$ Laode Monto Baouto, lecturer of Social and Political Science, Haluoleo University of Kendari. For academic interest, the author can be contacted through the office address: Kampus Hijau Bumi Tridharma Anduonohu Kendari 93232, and email address: laodemonto@yahoo.co.id.
} 
so that local culture began to be forgotten. Another factor is the lack of public awareness to the importance of cultural identity role as a nation. As a local cultural identity of the nation, it should be continued to maintain as well as ownership of authenticity that cannot be recognized by other countries. However, the influx of foreign culture is still required, but these should be in accordance with the cultural personality of the nation, as a country also needs help from other countries to be influential to the development of the country (Abdullah, 2006: 75).

The influence of globalization on the one hand, raises the negative influence of the culture of Indonesia nation. The norms containe in the nation's culture of Indonesia slowly began to fade. The rapid development of science and technology along with intrinsic values imposed on it has raised the issue of globalization and in the end showed a new value of the unity of the world. Radhakrishnan in his Eastern Religion and Western Thought (1924: 32) stated for the first time in the history of mankind, that the awareness of the unity of the world makes human being, either like it or not, in the East and West have been fused and never separate again. In other words the culture with a foreign culture remains is Indonesia. When East and West United, is there still the culture characteristic of Indonesia? Or Indonesia dissolved in the culture of another nation without leaving the slightest national cultural value system? Therefore, there is the need to defence the social aspect of Indonesia's cultural identity as a nation. The trick is to the cultural filter that is coming into Indonesia and the preservation of the nation's own culture.

For the people who are trying to develop traditional culture became a part of modern life, they will certainly continue to strive to modify the forms of culture which still patterns the past into a commodity that can be consumed in modern society. The type of Indonesia local culture should not become extinct, the successor of the younger generation should also be proud of the local culture (Abdullah, 2006: 65). In line with the Jenkins and Watson (2004: 115) emphasized how important the role of local wisdom as a strategy to face the challenges of "cultural imperialism" and "culture" of its homogeneity. A critical local wisdom plays a role in cultural exchange through global media and presented them back, and confirmed by Watson that the factors of global local wisdom products will transform into a meaningful and in accordance with the conditions of the socio-cultural life of the local community, as a form of "media convergence". In the social and cultural discourse, it is difficult to define and deliver the restrictions against local culture or local wisdom, considering it will be associated texts and contexts, but etymologically and scientific knowledge, it seems that the experts have been working to formulate a definition of local culture or local wisdom. As a study, and then to be studied and tried hooking in the present context. The definition of the first local culture is based on visualization of culture in terms of the structure and form, as expressed in the following Ranjabar:

In the cultural principle views the structure that consists of: (1) cultural superculture, is valid for the entire community. Example: national culture; (2) culture, more specifically, for example based on the ethnic, profession, region or area. Example: Sundanese Culture; (3) a special subculture, is once in a culture, but once this is not contrary to the parent cultures. 
Example: mutual culture; and (4) counter-culture, form similar to sub-culture that is part of the culture, but the counter-culture is contrary to its culture. Example: the culture of individualism (Ranjabar, 2008: 145). The structure and local culture are seen at the highest levels culture. It is based on a scheme of social cultures in Indonesia, which consists of the pluralist communities in the structure of social, cultural and economic (multicultural). Jacobus Ranjabar (2006: 150) said that judging from the compound nature of Indonesia, then society must accept the existence of the three groups that each culture has its own characteristic. The third group of the culture are: (1) ethnic culture (better known in General in Indonesia under the name of the cultural region); (2) local public culture; and (3) of the national culture. Koentjaraningrat (1998: 23) saw the local culture associated with the term ethnic group, to which his own ethnic group is a group bound by a human consciousness and identity will be ' cultural ' unity. According to Judistira (2011: 141) local culture is complete regional culture and regional culture are essential parts in the bed of the national culture. Inheritance of katoba great value particularly local wisdom culture to younger generations should be a concern of all parties.

\section{Problems}

How Is The Existence of Cultural Tradition Values In The Community Local Wisdom Katoba Muna As The Development Of Social Science For Elementary School Learning Materials?

\section{Discussion}

\section{Cultural Katoba in Muna Historical Perspective}

Muna, historically is a remain area of the wheel of history, more marginalized from the history of the Buton according to some historians, including neglected history (Zuhdi, 2010). Began from the formation of the Regency Muna from the status of selfgoverning at the end of Muna, i.e. when replacing La Ode Pandu in 1947. With the formation of the administrative region of Southeast Sulawesi 7 as a result of abolished area Laiwoi and afdeling Buton on Southeast Sulawesi Governor Decree number 181951 Muna changed its status to kawedanan and headed by KPN (head of Government), the same status that is experienced by kewedanan Buton and Kendari, Kolaka,.

In struggle to form its own district, Muna, experienced some difficulties and constraints of both the present and the Centre of the region. The efforts to make South East Sulawesi which was formerly a county of the province has yet to get the approval from the Minister of the Internal Affair and only approve the establishment and expansion of two government, Kendari and Kolaka. After a long struggle, Muna was designated as a level II Region Southeast Sulawesi through Act No. 29 of 1959 along with other city in Southeast Sulawesi(Buton, Kolaka, Kendari). Muna at that time consisted of four ghoera (district), namely, Tongkuno, Lawa, Katobu, and Kabawo are considered not sufficient to form an independent County, then substitute meetings and lobby with some community leaders, Wakorumba, Kulinsusu and Tiworo Islands, which at that time had its own district to join in the Government District of Muna. Then, on March 2, 1960, Muna 
Regency is established formally with the first Regent Laode Abdul Kudus (Radar Buton, May 30, 2009). Muna's struggle to establish an independent autonomy region was not easy. The struggle has already started since the time of the Kingdom and the Sultanate of Buton. Nowadays, the struggle is not for Muna political to form autonomy regions themselves, but for social, economic, and culture to be able to survive and exist at the core of the global community. Socially, the Muna's public system is similar to Buton, where the Division of the social stratification applied the Kings and officials system.

Coating social system in society, for example, the position of sultan of Buton and its officials are limited only to the authority of the Queen's descendants Wakaka. Similarly, three officials, namely, the Kingdom of Buton sapati (Prime Minister) and Kenepulu (the Prosecutor). The determination of this stratification is performed during the Dayanu Ikhsanuddin, the Sultan of Buton IV as a result of a deal with King Singga and Kenepulu Sapati La La Bula. Therefore, the determination of such caste system is to preserve the linkage of Kings and reserve only to noble family.

Initially, the Kingdom was based on four classes of Muna; that was the King, the Wamelai, the Kamokula, and/Mieno the multitudes (Burhanuddin, et al, 1977). The King was offspring of Beteno ne Tombula or Baidul Gadoh; the wamelai is a community descended from groups of ships stranded Sawerigading Muna and then formed the colonies and then lifting Baidul Gadoh Muna as King; the Kamokula is the community that comes from the head of the village and the rest are the multitudes who do not belong to the third group. The elites in Muna society consists of two classes, that are, descendants of groups of Sawerigading became known to the Beteno linkage and Wamelai Mieno ne Tombula appointed as King and produce offspring of the Kings of Muna. The relationship between the King and the elite of the elite in the Sultanate of Buton primus interparis is described as the relationship between grandchild and grandparent and the walaka call the sultan as the grandchildren.

At the time of the La Elangi, the differences between two societies is more emphasized bytheexistence of theprohibition to marry women with male kaomu walaka assuming that there may be a grandfather married his granddaughter. With two of those categories, the Wamelai Mieno as the first colony community Muna (primus interparis) is considered to be second only to the aristocracy of the linkage of Kings. They have a primary function as a Royal Council and the right to raise and lower the King in addition to their rights as ruler of the region of origin. Primus interparis in the community is made up of four regional Muna Mieno and four region Kamokula. The system of social stratification in society Muna is first during the Sugi Manuru, Muna the King V. Since the establishment of Sugi Manuru assumed the title of Omputo Mepasokino Adhati (an expert confirmordinance is customary). At the time of the sugi was the highest in the communities Muna as the holder of executive power, a descendant of mieno as intern legislative power, and the sons of kamokula as the holder of the judicial power (Tamburaka, 2010). The factional Division can be described as follows:

1. The kaomu, a community group of bloodlines boys Sugi Manuru and his Queen.

2. The walaka, a community group of bloodlines girls Manuru Sugi (Wa Ode Pogo) and Empress. 
3. The anangkolaki who comes from a line of 7 boys Sugi Manuru with concubines or also called fito bengkauno or 7 magnifying the country.

4. The ghoera papara, a descendant of the first four kamokula ghoera Kamokulano IE Tongkuno, Muna Barangka, Lindo, and Wapepi (Maradikano Ghoera/Papara).

5. The poino kontu lakonosau (a magical stone, a piece of wood), consisting of four early, mieno as a result of the Division of koghoerano, which in the community called Buton Bonto Ogeno. However the maradika is also there that translates as a descendant of the province of lindano (Kancitala, Lembo, a turtle, and Ondoke) and was a descendant of kafuwawe (the first wamelai mieno waiter). This group served as a maid or servant of lakina wuna.

6. The ghata or slave (Couvreur, 2001; Burhanuddin, et al, 1977).

These classifications are grouped into three major classes: nobility consisting of kaomu and walaka; and the maradika or the common people of papara/ghoera and paino kontu lakonosau; and the ghata or slaves. The slave category is as prisoners of war, servitude because of devotion, and debts that cannot be paid. The debtor will be independent if he pay his debts. In addition, Muna's community has life cycle ceremonial which is began from the time of conception, pregnancy, birth, when the death come even the death itself. Many dietary restrictions attached pregnant woman that she cannot speak and give inappropriate, as well as the prohibition for the husband to slaughter animals or cut something that is trusted by the community can lead to defects or Muna mental retardation at the child when born. The ceremony during pregnancy in the community known as Muna Kasambu which means give meal which begins from the shaman or the elderly with a view to the child who would be born rich sustenance has also survived in the process of the birth of both the mother and her baby. The ceremony is generally only carried out for the first pregnancy at seventh or eight months of pregnancy. After the baby is born, they held kampua ceremony at the 4oth day of child and follow with the ceremony of cutting the baby's hair called kaalano wulu. The ceremony for the baby down the ground is also done by people called kaghabui Muna, by carry a child in his arms eastward and headed toward each skipped intersection sprinkled ash kitchen with the intention that the child survived, sickly and not shunned from Ethereal. At the age 10-14years old there is katoba's ceremony as ritual Islamization and for the adult girl there is ceremony for marriage preparation called Caria. After the marriage preparation ceremony, there is also ceremony to prepare the girls for her domestic life.

\section{The Purposes of Katoba Cultural Traditions}

From the previous section, that was initially meant to be a celebratory ceremony katoba ceremony of passage from childhood to adolescence, beginning with the circumcision, as a sign of a child to Islam. Besides the goal, katoba people was aware of their responsibility as Muslims, either to God, parents, sisters, or to people and even the whole universe. 


\section{The Katoba Cultural Traditions Values Ritual}

Before entering the show, a Katoba boy at the age between 6-12 years old should promise first to both men and women. If the child is already circumcised, then the child can already Islamized (dikatoba). The process of circumcision can be performed at the same time that is after the child circumcised, then immediately " dikatoba ' or may be circumcised only once while the events ' katoba' can be done another time. While things are taught to children in procession katoba is as follows:

1. Uttered two sentences creed as the new incoming people converted to Islam.

2. a child must honour and respect the elderly men because the elderly man was in lieu of Allah SWT. The old man here is not only the father but also almost all the elder must be respected and valued.

3. a child must respect and appreciate women's parents because the parents of the woman as successor to the Islamic prophet Muhammad. The elderly woman here not only the mother but all parents are nearly all from her mother or older must be respected and valued.

4. a child must respect and appreciate my older brother because in lieu of the Angel Gabriel. Sister here not only became her sister but all older people should be respected and valued.

5. a child should cherish and care for my younger brother as successor because of all the believers. Sister here not only became his sister but all the younger guys it has to be appreciated and cherished.
After all five things above have to be taught to the children, then the children are introduced to the types of water can be purified. Water-the water of which is oeno ghuse (rain water), oeno kamparigi (water well), oeno tehi (sea water), oeno aloma (water dew), oeno saliji (snowwater), oeno laa (Lake/River water) and oeno lede (tap water). Later a child is taught that he must run away from the commandments of God and the restriction. In this stage the child must abstain from prominently prohibition of God for example do not steal, do not gamble, should not drink alcoholic beverages and others. In addition, the children are also taught to care for the environment, for example should not damage the plants, if you see a rock on the highway, the child should get rid of him so that others who pass through the road that's not tripping the stone, and others. Also emphasized that if the child has been Islamized then there should not be any more shows her body to not mahram.

Next, the Priestrecited prayers to children who have been Islamized, in reading this prayer preceded by ceremony burn incense and don not forget "haroa" or a condition must exist. The offerings here does not mean to worship idols, but the contents of the offerings here are rice, fried chicken, chicken goulash, cucur, diamonds, sugar-apple cake, hard boiled eggs, fried eggs, fried banana, ripe banana that has not been peeled and a variety of other snacks. The contents of this should not be taken haroa/eaten by other people and can only be eaten by children, who underwent the process, but the contents of the haroa katoba last if not can be spent by the children, then it can also be given to other people and only the child who can give it, cannot be represented. 
Implementation of the ritual culture katoba begins with:

1. Tobhotuki. Tobotukiemo itua rabunto modaino ne Allah ta'ala, ne kamokula moghane, ne kamokula robhine.To bhotukiemo itua!

2. To soso. Tosoemo itua rabunto modaino ne Allah ta'ala, ne kamokula moghane, ne kamokula robhine. To sosoemo itua!

3. Dofekakodoho.Dofekakodohoemoitua rabunto modaino nae wine nae fua ne Allah ta'ala ne kamokula moghane, ne kamokula robhine. Dofekakodohoemo itua!

4. Tofokomiina. Tofokomïnaemo itua rabunto modaino naewine nae fua ne Allah ta'ala, ne kamokula moghane, ne kamokula robhine. Tofokomiinaemlo itua!

5. Amanto tao tehi. Miina natiwora Allah ta'ala amanto kabholosino. Nikonano ama maitu suano kaawu amamu sakotu-kotughuhano, taaka lahaelahae membalino kamokula maghane amamu itua, tabeano do tehie.,

Next syarat/isi katoba:

1. Inanto tao tehie, mina natiwora nabi Muhamadhi inanto kabholosino. Nikananndo ina maitu suano kaawu inamu sakotu-kotughuno taaka lahalahae kamokula robhine inamu itua, tabeano do tehie.

2. Isanto tao tehie. Miina natiwora malaikati, isanto kabholosino. Nikonando isa maitu suano kaawu isamu sakotu-kotughuno, tamaka lahae-lahae foliuno umuru isamu dua itu, tabeano do tehie.

3. Aintotaotehie, dotehine aimaitu beano dopototoane bhe do tehi sapada intaidi o mukmini. Nikonando ai maitu suano kaawu iamu sakotu-kotughuhano, tamaka lahae-lahae neliumu umuru aimumo dua itu. Tabea do tehie itu.

4. Koise de ala hakuno mie bhainto, ane do faralu de salo ne kobarano. Sakotukotughuhano mahengga de ene we sala bhahi de ene inta, atawa o bulawa, o manikamu, o doi, mahengga se ghiu bhe, se bhini ka roo, se katampuno deu do foworaane koferebuano. Ane mina bhe mangakuni ferebuahano do oawaane amanto, maka amanto no owae te masigi no salamitigho do pakee.

Further requirements/contents katoba:

1. Inanto tao tehie, mina natiwora Muhamadhi inanto kabholosino the Prophet. Nikananndo ina maitu suano kaawu inamu sakotu-kotughuno taaka lahae kamokula robhine-laha inamu itua, tabeano do tehie.

2. Isanto tao tehie. Mïna natiwora malaikati, isanto kabholosino. Nikonando isa maitu suano kaawu isamu sakotu-kotughuno, tamaka lahae lahae umuru isamu foliuno-two, tabeano do tehie.

3. taotehie, d.o. Ainto tehi ne ai maitu beano dopototoane bhe do tehi sapada intaidi o mukmini. Nikonando ai maitu suano kaawu iamu sakotukotughuhano, tamaka lahae-lahae umuru aimumo two neliumu. Tabea tehie do it.

4. Koise de ala hakuno mie bhainto, ane the faralu of salo ne kobarano. Sakotukotughuhano mahengga of ene ene of bhahiroomweinta, atawa the bulawa, the manikamu, the doi, mahengga if ghiu bhe, if bhini ka roo, if katampuno the koferebuano foworaane gave. Ane 
ferebuahano of oawaane mangakuni bhe mine brobe, maka brobe in masigi you in salamitigho owae of pakee.

\section{Katoba Process Circuit and the Meaning of the Values Embodied in it}

In practice, the cultural traditions of the katoba community in Muna have a specific set of activities or procedures that must be followed. Each set of activities contains the values of the religious, social, economic and historical. Norman (1997: 27-39), related to a series of events in the town of Raha Katoba traditions and values what is contained therein posited:"The provision that must be followed in the performance of the ceremony was like katoba on stages katoba ceremony. These stages include a series of four activities, namely (1) the preamble or introduction, (2) the terms of the toba); (3) core/contents of the toba (4) cover of each circuit or stage of the activities mentioned above contains a specific value. Any values that are contained in each set of activities or phases of katoba cultural traditions will be outlined in the following image below.
1. Bhotuki
2. Tososo
3. Fekakodoho
4. Fekomiina

5. Dotehie kamokula

6. Dotehie isanto

7. Dotehie ainto

8. Hakunaasi

9. Oemongkilo

First, Tobhotuki (disconnect). Tobotukiemo rabunto modaino ne ituaAllah ta'ala, ne kamokula, ne kamokula robhine moghane.To bhotukiemo itua. The value that is contained in the concept of bhotuki is to believe that humans did not escape the malpractice (SIN), also have religious values with indicators (1) believe in the power of God; (2) conviction of human events off the ground; (3) the belief that human beings are going to die; and (4) belief in destiny.

Religious values from the Katoba ceremony examined in the process of integrating local culture in learning subjects Social Science-Elementary school to enhance student's appreciation of local culture, because it is more relevant when integration is examined with Religious subjects. Therefore, this research will focus on integrating some of the socio-cultural values, religion, history and politics that is embodied in Katoba cultural traditions. Second, Tososo, is regretting any act or behaviour that is bad/ evil has ever done so far. Third, Fekakodoho, is away from and prevent themselves from deeds or bad behavior to God Almighty and to parents. Fourth, Fekomiina, is negated or forgotten deeds and evil/bad behavior ever done for this and trying to improve myself by always doing well. Fifth, Dotehie kamokula, is the honor and respect both parents as a symbol of recognition and obedience to the commandments of God and the prophets/ messengers. Sixth, Dotehie Isanto, is the honour and respect which became a big brother as a symbol of assurance to the Angel Gabriel as a creature of God.

There are some social and religious values that are contained in the activities of the katoba procession. Social value for instance is togetherness, mutual and willing to make sacrifices for their fellow human beings in order to find a solution to the problem in an effort to prosper the human race. While religious values that are contained here, namely the value of obedience to the commands of Allah SWT and stay away from any restriction as the capital base of the 
safety and happiness of the world and the hereafter. Seventh, Dotehie ainto is honor and respect anyone who became a sistersister as a symbol of respect for Muslims and established the fraternity. Eighth, Hakunaasi is an act that should not be taking someone else's goods without the knowledge of their owners. A child has to know the rights and compulsory Oe mongkilo, is a kind of holy water or water that is used for ablution before prayer.
historical.This studyaddressed socio-cultural values associated conceptually with Social Science for elementary school curriculum. This is because one of the goals of this study is to develop learning materials to increase knowledge of Elementary school, Social Science, attitudes and student's skills against local culture (Katoba) in an effort to increase the mastery of subject matter Social ScienceElementary school. therefore, in the develop learning materials will be integrated with local cultural values that are relevant. Local

Table 4.1 Series of activities of cultural traditions Katoba and system values that are contained in it

\begin{tabular}{|l|l|}
\hline $\begin{array}{l}\text { A Series Of Ac- } \\
\text { tivities }\end{array}$ & Value \\
\hline Tobhotuki & $\begin{array}{l}\text { Religious values: Decide misdeed committed during this time. Believed } \\
\text { to be the power of God; The belief that human beings must never do evil } \\
\text { (bad); The belief that human beings are going to die; Belief in destiny. }\end{array}$ \\
\hline Tososo & $\begin{array}{l}\text { Religious values: love of cleanliness; Humanitarian responsibility to- } \\
\text { wards others, regretted the deed was bad all along. }\end{array}$ \\
\hline Fekakodoho & $\begin{array}{l}\text { Social: Togetherness (supportive and motivated to achieve a goal). Poli- } \\
\text { tics/history: the value of fighting, stay away from evil/bad. }\end{array}$ \\
\hline Dotehie kamukala & $\begin{array}{l}\text { Social value: Respect or appreciate the parents; Self-reliance; Clever take } \\
\text { advantage of opportunities; Please help and mutual cooperation. }\end{array}$ \\
\hline Dotehie isanto & $\begin{array}{l}\text { Social: not spiteful; Pardon; Willing to sacrifice for one another. Respect } \\
\text { or appreciate my brothers. }\end{array}$ \\
\hline Dotehie Ainto & $\begin{array}{l}\text { Social Affairs: Cooperation; Mutual; Willing to sacrifice for one another. } \\
\text { Dear brother-sister. }\end{array}$ \\
\hline Hakunaasi & $\begin{array}{l}\text { Social: compassion; The Fraternity; Empathy in the tribulation. Should } \\
\text { not take people's stuff laoin, without permission. }\end{array}$ \\
\hline Fomiina & $\begin{array}{l}\text { Social: Nullify, Raising cooperation; Unity; The Fraternity; Healthy com- } \\
\text { petition. } \\
\text { Politics/history: the value of fighting for achieving the objectives } \\
\text { Art: Creativity. Technology: Innovation }\end{array}$ \\
\hline
\end{tabular}

From the table above it can be concluded that in the tradition of katoba as one of the local Muna society cultural contained many positive values that need to be preserved and developed. Positive values are the values of the religious, social, political, economic, and cultural values (Katoba) curriculum relevant to the Social Science-Elementary school is the social values, culture, economics, politics/ history and art/creativity and religion. 


\section{A Review of Katoba Philosophical Culture and Learning Social Science}

The katoba philosophy that is built upon the thought that society expects to her life in orderly. Katoba compiled from a series of norms, doctrines and laws by the Customs and religion of the deceased to govern the interaction of life patterns society in all decisions, actions, goals, behavior and actions. Therefore, in katoba ceremony tradition there is a form of religious moral teaching (absolute ethics) which gives a very big role towards the formation of character, mindset, attitudes, patterns and patterns of human action in a life. Katoba affects public confidence that Muna admitted that there is no God who was worshipped besides Allah, and Muhammad as His messenger, mutual respect and respect among fellow human beings. (especially to fathers, mothers and siblings), and do not take without permission or steal other people's stuff (La Fariki, 2010-12: 24). It is expressed that the source of value in the speech are cultural katoba, familiar and personal. The cultural advocates tend to assume that the values will be applicable in every aspect of life, as the place where the individual was raised. For the community, constitutes katoba Muna ritual life cycle, as a change of status from childhood into adolescence. Katoba implemented in boys and girls at the age around 6-12 years old, which considered relatively mature enough for Muna society in religious moral values and customs. Therefore, it is a ritual of rite de passage or ritual threshold/transition (threshold) that celebrates the presence status of adolescence in a child called also with coming of age ritual. The Ritual was carried out after the ceremony generally katoba circumcise called kangkilo. Katoba is implemented by the ceremony of the parents as one of the obligations and responsibilities that must be done in addition to his son, because the ritual for the community of Muna is generally regarded as a mandatory thing. The importance of this ritual because when it is not be done, there will bejudge for a child who misbehave and disrespectful. In the vernacular of the condition with designated communities anahiamaitumiina namangkae wambano toba means children who not follow the tips that are taught in the tradition of cultural katoba (Zainal, 2011: 35-37).

Therefore it is important conception that a learning based on the communities local wisdom. Because social problems are always evolving and constantly changing so learning should be adjusted, whether material or content presentation of learning techniques. The subject matter is presented with a fun way because according to Winberg (Mulyana, 2008: 31) provides that a person will learn optimal if in an environment which is not tight, the environment that provides opportunities for learners to develop its potential. Any study must be done by the method of learning by doing. Mulyana (2009) revealed that the main task of a learner is to be himself. The creation of the new reality of "cultural katoba" as their appreciation of the local culture, with the following considerations: First, the Social Sciences are currently learning ambience with a view of modernism, where education is more directed in mechanical engineering problems so that it became the centre of attention when the material and learning system with orientation on results rather than on the process. 
Reproductive education Format of modernity has made learning as a lesson into one of the Social Science that are not exciting and boring for early students. Findings of this research and previous research justifies the statement above, that the Social Science more education-oriented structure of the mastery of scholarship (academic source) from the reality of social culture. Social Science education have been over loaded charges, less in accordance with the children's learning motivation and orientation (Hasan, 1993; 1996; 2002). Social Science teachers tend to be tied to either the content of textbooks, as well as the material content that are causing the learner needs and interests in learning neglected (Lasmawan, 2008). Social Studies in Indonesia which is the embodiment of social values of value developed in Social Science study yet so visible application in daily lives of learners (Syaodih, 2008). The low of learner's appreciation toward Social Studies because lessons are hard to understand and to be memorized (Pharisees 2005).

Second, one of the aspects of education which emphasized the perspective of postmodern education is as important a dimension of ethics. This will bring the learners have empathetic attitudeand social care of people who are outside the margin of the social, cultural, and religious students or commonly referred to as outsiders. Because education is not a preparation of life but it is life itself. The education postmodernism perspective is relevant to the mission and goals of the Social Studies. Social Science subjects are subjects that are expected to play a role in the formation of attitude of good citizenship is reflective, educational efforts, Social Science can serve as a critique of social life (social studies as social criticism). Social Study will develop critical thinking skills (critical thinking), one's personal development (social studies us personal development of the individual), and equip a person's ability in self development through a variety of social skills in life (social life skill). Thus the learning development strategies need to be developed, Social Science that equip learners the knowledge, skills, attitudes, and values that shape the self-image of human being who has identity and capable of living in the surroundings of the people. One that can be done is with the integration of local cultural values that are in the environment of the learners (cultural values deriving from katoba) in Social Studies. Through the knowledge of the reality that exists, learners can get to know Her and oversized $\neg$ creation of the creator, the natural surroundings for potential digging that were developed for the welfare of themselves and their society.

Ultimately, learners are able to reposition its role as social beings with all the realities it faces. Third, the learning materials developed by the cooperative learning and clarification combination of values that are packaged in a tournament will develop the social sensitivity and stimulate brain intelligence to analyze the problems and thinking of the action the solution. Through learning values clarification learners are taught about "ethical relativism" and how humans develop the value itself. Implementation model will have an effect on the growing awareness that tolerance is a virtue that is commendable and the highest. The purpose of this study is in line with the view of postmodernism that "Judging is a sin" (being judgmental) and "thought the narrow and petty" (being narrow-minded) 
once considered the only Social Studies that have learning the truth " and " trying to impose its values on others '. The process of discovery of the value by the learners through the clarification of values will make the spirit of equal in creation (equal in creation) and a common goal to welfare together as core values.

Fourth, the development of learning materials, Social Science as a strategy that Social Studies is multidimensional and multidisciplinary, able to provide transfer of knowledge, infiltration the nation's cultural values, and morals in the realm of practice so as to develop the wisdom knowledge, awareness, attitudes and behaviour (mode of action) against the diversity of learners. The process creates sense of the Social Studies that come within the framework of co-existence and more able to participate in creating a social relation than pro-existence in a number of social, culture, and religion in Indonesia. Thus the development of learning materials is also using a complementary approach that gives priority to the perspective of other cultural communities (outsider). The steps include an empathetic value clarification to values that are found and chosen by learners or other groups in their perspective. Because it will produce knowledge that empathy is neutral and does not assess (with suspend disbelief imagination), apart from the reactions and appraisals. Promoting diversity is the local wisdom is also the local narrative, in postmodern cultural diversity principles can be drawn as 'way of thinking' that any one particular group was declared one specific culture should be considered as a good thing, as with other cultures.

\section{The Learning Condition in Elementary School Based On Social Science Cultural Values}

Social Science-Elementary school learning conditions in Muna society are as follows: first, the teacher: (1) the subject matter of many Social Science, so they need special methods to make students fun, active, creative, and motivated to learn the lesson objectives, Social Science as well as achieved so learning meaningful for students of Social Science; (2) the use of special methods because the Social Studies-based learning value, then the learning transfer not just Social Studies knowledge but also the transfer of value. Therefore, it takes mastery of knowledge and approaches to values education in Social studies. The fact, teachers have to understand the various approaches of values education and its implementation in the Social Science study; (3) Social Science Curriculum provide sufficient leeway to develop a variety of learning methods to support the success of the learning method, but because of the Social Science, Social Science are not comparable to the allocation of time learning, teachers prefer to use methods that have been mastered, namely lectures and discussion groups. Second, the idea of developing a learning model based on Social Science to katoba cultural values enhances the appreciation of the students local culture that is supported by the views of Social Science teachers, purpose, and role in strengthening student's appreciation of local culture.

The problems in Social Science came from the perspective of students as follows: first, the Social Science only base on the text book and less student's environment utilizing as a learning resource. This makes 
Social Science as a boring lesson, does not encourage students to think critically, and less developed sensitivity to the social environment. Second, students never made a simple bouquet of Social Science or explore the cultural superiority of its territory as a form of pride students to culture regions. These conditions have an impact on the emergence of the stigma that the Social Science is less beneficial to everyday life and a lesson. Third, the view of students against teachers, Social Science is less interesting and monotone because students just listen to the teacher. Social Science lessons would be more interesting if it is supported by sources in the learning environment and teachers who facilitate the learners to describe the values that can be imitated from subjects that are discussed so that learning can be useful for student life. Fourth, they agreed that the tradition of local cultural katoba Muna community must be preserved. Katoba is in the system value, the individual will determine which behaviours to do and which one should be avoided. This will be apparent in the attitude and behaviour of the real in the community association as the embodiment of value systems and the underlying moral.

\section{The Development of Learning Materials, Social Science}

Through the theoretical study, the framework initial the results of the study and the design of learning materials that is developed by adopting social and cooperative learning model and incorporating the clarify the value that is packaged in a tournament. Cooperative learning is made up of six stages, namely (1) delivering the goals, (2) convey information, (3) organizing in groups, (4) guiding work and study groups, (5) evaluating, and (6) giving the reward. It refers to the achievement of learning objectives competencies and competency standards and core basis, i.e. on increasing mastery learners against Social Science material, the strengthening of character, i.e. the ability of learners in conducting values clarification deriving from cultural values and awareness of the students against the national identity. Formulation of goals laid out is a reflection of the learning objectives achievement with indications of increased mastery learners against Social Studies material as well as strengthening the students ' attitude towards and appreciation of local culture.

This approach is carried out by means of integrating local wisdom values into SK and $\mathrm{KD}$ to be taught. This was seen as not to disturb the process of teaching and learning activities in school and can be accepted by all learners withouthaving toadditionalteaching time of instruction. The learning materials, is developed by using the handbook of teachers and learners and the workbook/LKS.

For local wisdom values katoba cultural traditions developed from existing ritual significance in culture katoba. The selection of values that will be developed is adapted to the material values of learning and character education. The implementation of Social Science in earning class with the allocation of meeting time each 2 hours of lessons or 2 x 35 minute. This strategy is done because of cultural values in the class will be socialized katoba $V$, therefore despite the use of Postmodern paradigm, but by no means eliminated the existence of the SK and KD.

The Postmodern curriculum is used as a basis for curriculum development unit level of education by using the components of the four elements thus r's such as richness, rigor, relation, and recursion, are used as a basis of socio-cultural environmental context that place learners in an effort to enrich 
the learning materials, integrating katoba cultural values so that Social Science in school learning meaningful to the lives of the learners. The media and learning resources based on the Decision Letter and $\mathrm{KD}$, the material taught, learning activities, and indicators of the competencies achievement. On this model, media, resources, and learning tool that can be used is basically a teacher, which can be either printed or electronic media, ranging from simple to modern high-tech media. Selection and use of media, sources, and tools are not determined specifically but need to pay attention to the real conditions in schools, in particular the availability and capabilities of teachers in using a variety of media. Media, sources, and tools among others in the form of local culture (environmentalist), handbook and source books, Social Science, LCD and the internet generally has been owned and operated by the learners.

The procedures and instruments of assessment processes and outcomes of learning tailored to indicators of competence achievement and refer to the standard assessment. The goal is to find out how far learning implementation has been managed to reach goals set. Therefore the assessment is undertaken include assessments of processes and results. The assessment process is directed to assess the learner's activities and behaviours while the assessment results are intended to assess mastery learner's learning material to set.

The assessment process on the implementation of the Social Studies materials is done by doing observation activity to the learners when learning takes place. For example, at discussion, work on individual and group assignments, presentation, argumentation at the time of the response, and others. As for the assessment of results is done using the technique of test and non-test. Tests used to assess mastery of competencies according to the learning objectives. Attitude scale used to measure the attitudes of learners towards the appreciation of local cultureeducation related Social Studies-based cultural tradition values katoba and philosophical meaning of cultural rituals and attitudes learners katoba against katoba. The evaluation study was compiled with reference to the learning objectives for the evaluation was held to measure the achievement of learning objectives.

The test was developed as a means of evaluation consists of multiple choice questions to capture knowledge learners against Social Science materials, the test scale for measuring attitude toward the student's appreciation of local culture. In general the purpose of the development of learning materials, Social Science, i.e. so that the learners are able to find the critical values that can be imitated or avoided of learning material. In addition material is expected to give the effect that means against strengthening appreciation and attitude of the students towards the local culture. In order to build awareness and develop the ability of students in identifying their own values and others, then the implementation of cooperative learning, combined with the approach of the value clarification (VCT). The incorporation of Cooperative learning model of Learning and Value Clarification Technique based on that moral development is closely related to cognitive development and the result of social interactions.

Social studies develops the learning material through the ability to intelligently protégé, is able to understand and find moral values in social interaction dynamics that 
is full of challenges, especially on the social conditions which are not conducive to the development of rated moral values. Learning teaching techniques is a VCT to assist learners in search and specify a value that the well in the face of an issue through the process of analyzing existing and ingrained in learners. This approach will help the students to understand and find the values the meaning of events in depth (ultimate meaning).

Learning steps developed in accordance with the steps of learning cooperative learning model combined with the clarification of values. The merger of two models of learning in its implementation still refers to the learning materials according to Candy from Diknas No. 41 in 2007, consists of three stages: (1) the apperception, (2) core phase, consisting of exploration, elaboration and confirmation, as well as (3) stage finale. On the implementation of the process of learning changes the learning steps on the clarification of values. In the early stages of learning plan consists of seven steps, namely learners (1) select a value; (2) the classifying value through analysis of the issue under discussion; (3) take into consideration the consequences of the selected values; (4) the value of reason "in the context of the problem examined; (5) the express option (specify the optionvalues thatare relevant totheproblems and are delivered in class discussions); (6) actualize option value (shows examples of attitudes to be developed and which should be avoided); (7) internalisation the value (the learners position and stating the reason, test the same in some situations and actualize the selected values in the life of the community).

The seven steps of clarification a value reflect the integrity of the educational dimension of productive and efficient streamlined into three steps. It is intended that teachers ready to evaluateand strengthen the activities at each stage of learning. The first step to the third dimension including cognitive (emphasize rational capabilities). The fourth and fifth dimensions reflects the affective (pride and recognition), the sixth and seventh step reflect its psychomotor dimensions (concrete action that is continuous and patterns).Values clarification approaches give emphasis on the real value of owned by someone based on a variety of background and experience. Therefore the purpose of education is to develop student's skills in conducting the process of judging. In line with the view, the role of the teacher in teaching value is to encourage learners with relevant questions to develop the learner's skills in the process of judging. On the implementation of the model, the learning steps after extensive trial experience, namely the addition of the stage orientation. This stage blends with apperception.

The measure of learning process orientation includes Social Studies being apperception, exploration, elaboration, confirmation, and cover. Implementation of this learning model is the incorporation of cooperative learning model and clarification of values. Customize the orientation phase; the teachers are ready to learn by providing a description of the purpose of the study, the topic of the material to be studied, the student's knowledge of materials that have been provided earlier. The teacher describes the steps of learning that will be followed by the learners.

This orientation phase is very important in relation to the implementation of the Social Science; prepare the learning media and resources that can be used in the learning process, Social Science Orientation stage needs to be added in the steps of learning 
models in an effort to avoid confusion among teachers and learners in applying Social Science learning materials. This stage is very important as an early activity (including the apperception) because at this stage the teacher describes (I) the concept of value and the life of the individual and the community; (2) the source value, among others from the culture of the philosophical values of the ritual katoba culture; (3) the relevance of philosophical culture values katoba with character education; (4) the relevance of cultural values and character with the material to be studied; and (5) of the local culture as katoba must continue to be preserved.

The integration of socio-cultural values is deriving from cultural traditions katoba (ritual) that can be implemented because the symbol has a meaning for the community. To interpret the cultural value of this katoba, learners actively discuss the transformation of meaning for the formation of character. Through a process of self-learners assess indication, it gives meaning to the cultural values that can be imitated and decided to act upon the meaning. In this context of cultural values interpretation and transformation into value katoba, the character value is inseparable from social interaction.

The interpretive process has two steps: first, the principals specify objects that have meaning. Second, it involves the offender to choose, check, and performing the transformation of meaning in the context in which they are located. Through the interaction, individual learning build sense of self in the framework the self concept formation. Self concept is idea that beliefs, values, feelings, appraisals of self that will affect behaviour. Self-esteem (sense of self) and the concept of the self (self-concept) guide the behaviour and attitude of the person at this stage of self-fulfilment (self fulfilling prophecy). Thus "self concept and self" are built through social interaction (community) in an environment of cultural value systems katoba,teachesabout"valuehonesty,fairness, courage, peace and happiness" that will affect the learners behaviour in relation to God, self, other people and the community of the nation. With regard to the theory of symbolic interaction in the development of this model can be explained that the meaning can only be understood through cultural traditions of ritual katoba which translates to the values and cultural value systems ultimately katoba translates to knowledge systems. As a knowledge system, ritual meaning can change according to the interpretation of community supporters. Such knowledge systems are relevant and useful in everyday life. In this context it is obvious that human behaviour and environment are symbolic system.

Therefore the public members often allot (asystem of symbolsandmeanings).Mankind is assumed as spreaders, producing system of signs and symbols to impart knowledge as well as well as messages through the process of interaction. This symbolicknowledgestudy and examine the process in which people give the meaning to the world and behaviour in it. To interpret a symbol is not from his symbol, the symbol meant by hares instead of humans as its interpreter. In other words, the meaning can only be understood through intermediaries a symbol that translates the knowledge into value and translate the value into a set of knowledge systems. Through the cultural integration value in learning katoba, Social Science makes learning into meaningful, because the material learned in school is relevance to the context of the life of the learners. 
The learner's life relevant values are discover through the interaction of the group. It develops the learning materials "how era/learning process" found something meaningful not what outcome study. The effective learning is a learning that emphasizes the meaning and the liveliness of the learners so that learners construct knowledge seeking becomes meaningful. Social Studies will be powerful learning If it delivered in meaningful (meaningful) challenged (challenging) and active. Meaningfulness of learning for learners, Social Science is achieved with packing material that connects the knowledge, beliefs, and attitudes they earn both inside and outside of the classroom (contextual). As the materials are bound by the socio-cultural values of the nation, education, Social Science cannot be separated from the values and norms of the nation. The integration of cultural value is deriving from socio-cultural values "in learning katoba Social Science that will make the lessons become relevant or meaningful. One of the characteristics of education Social Science is the development and analysis of the value (value) as well as its application in social interactions (social interaction).

The exploration phase is a combination of teacher's activities that convey information and organize learners in group study with activity sorting and learners choose the value throughthediscussiongroup.Teachersconvey information about the material according to the learning objectives, orientation and activities associated with apperception. Learners in the Group began to search variety of learning resources and textbooks to identify, analyze problems to be Group work, describes the values in the context of events or problems that are examined. Values selecting and sorting actiities requires a process of thinking that involves mental operations, such as classification, induction, deduction, and reasoning.

The sense of thinking is the ability to analyze, criticize, and reach a conclusion based on a careful consideration of the inference. This thinking process is relevant to the learning theory of Bruner-"discovery" i.e. the search process knowledge actively by learners so as to give the best result for him.

Elaboration Stage, Learners appreciate the option value and express the value in options discussion groups and classes. Learners are cooperative and collaborative to discuss in their respective groups. Through class discussion, it confirms the learners to express the option values that are relevant to the problem. Teachers facilitate students to bring up new ideas, provide an opportunity to resolve the issue of analyzing and thinking of acting without fear. Learner's facilitating competed healthily to improve learning achievement.

At this stage, the thinking process regard to learning meaningful. To learn in meaningful makes the learner success in hooking information at the relevant concepts that contained in the cognitive structure. In the elaboration phase, learners are actively collaborate with his group, do (1) analytical process thinking, i.e. the ability to separatethe material into sections that is needed, looking for connections between the parts, being able to see how the various components relate and are organized so that it is able to resolve the issue at hand; (2) the synthesis is the ability in all related items and put together into a new roundness like the patterns and the structure of knowledge (3) final aspect is the evaluation, is an aspect which covers various aspects of earlier so that they can assert and express option value is by example. 
The implementation stage is the elaboration phase where learners express and appreciate the value. This activity provides the learners about "ethos," value "," confidence "," needs "to live together (to live together) people or other groups. Learners will learn how to respect the other, train to have a sense of responsibility towards the whole of life creation, animate, trained to be sensitive and their quick response to the things that lead to hatred, violence, and all new developments, and which threaten the life of the joint.

The core of the third stage, named the Confirmation where teachers and learners straighten miscommunication, give a false assertion and reinforcement from the results of the discussion. Learners with teacher's guidance do the reflections and summarize the results of the class discussion, it also stated the position and the reason, testing with some of the same situation, and actualize the selected values in the life of the school, community, and country. With regard to the activities of students at the confirmation stage, include the activities of learners in actualizing and internalization of the relevant value in daily life. Knowledge is not obtained passively by someone but through action.

This point relevant to the purpose of education value, named (1) helps learners to convert and identify their own values and values of others. (2) Assist learners in order to be able to communicate openly and honestly with others, (3) helping the learners are able to use the ability to behave rationally, and their own behaviour together. Therefore this Social Science learning materials put more emphasis on how the learners learn, not how the teachers teach. The teacher's responsibility in learning is stimulating and motivating the learners. The diagnose resolve the learners difficulties 1 as well as provide the experience to cultivate knowledge of the learners.

Learning is a process to build against material that is presented. The children cognitive development depends on how far theyareactively manipulating and interacting with its environment. Through the learning stages of Social Science, made the learners to: (1) formation of concept and understanding of self; (2) the objective attitude towards his own self; (3) the self-actualization; and (4) values and attitudes towards comprehension in personal and social life.

The learners able to understand and be aware of their status, predispose self capacity as a person in the context of the everyday life of the personal, social and cultural. The symbolism interaction explained that the establishment of the concept of selfin addition by the learners own self conceptualization as well by other people's perceptions of him. This will affect to the learner's behaviour as capacity and in the context of sociocultural life. These learning materials are relevant to the theory of humanistic learning, learning that the purpose was to humanize a man. The learning process is considered successful if the student understands his environment and himself. Learners in their learning process should seek to achieve self-actualization gradually. The role of the teacher is as a facilitator for the learners and the teachers provided motivation, awareness about the meaning of learning in the lives of learners. Teachers facilitate the student learning experience and assist learners to achieve learning objectives. Learners act as protagonists (student centre) who interpret the process of their learning experience and to understand and develop the potential of her positively and minimize potential negative nature. 


\section{Teacher Performance}

The progress of the teacher's performance over the socializing is done from learning materials that are seen growing to ability of teachers, among others: (1) drafting plans for appropriate learning permendiknas No. 40 year 2007, (2) use a variety of teaching skills, (3) compose an evaluation, (4) Guide and directs learners, (5) maintains the classroom, (6) create contextual examples for learning, Social Science, (7) using local values for the study of Social Science, (8) using the learning media, (9) put yourself as a teacher than as a guide. The teacher development of teaching skills showed that during the trial, teacher's skill in using a variety of teaching skills progress, can be seen from the teacher's ability of teachers do the Social Science learning stages, named apperception and orientation phase, exploration, elaboration, confirmation of which was the implementation of cooperative learning and joint clarification of values. The more important thing is that the teacher is not in dominant position anymore as the only resource in the learning process. Building the critical dialogue between teachers and learners, and peer group of learner is similar to the meaning of relevant learning material in the context of socio-cultural environment of the learners.

Teacher's creativity in developing the teacher learning ability look like a real compose an evaluation tool, it means that teachers have organized the evaluations that can measure the learning objectives. In addition teachers also conduct an evaluation at the time of the process of learning through observation. Teachers work during the evaluation process and the end of learning. Thus there is awareness in teachers and learners that the process of learning is as important as learning outcomes. Therefore the teacher not only develops knowledge learners but also the character and attitude of the learners. To increase in learner activity during the following learning depends on the role of the teacher as a facilitator and provide reinforcement on learners to browse through variety learning resources, it means that the guidance and direction of the teacher to make students become active.

\section{Conclusion}

Based on the description above, it can be conclude that the culture tradition katoba as one form of local wisdom Muna society contained many positive values that need to be preserved and developed. The positive values are the values of the religious, social, political, economic, and historical/ art/creativity. This study addressed sociocultural values that is associated conceptually by Social Science- Elementary school curriculum. This is because one of the goals of this study is to develop learning materials to increase knowledge of Elementary school, Social Science, attitudes and skill students against local culture (Katoba) in an effort to increase the mastery of subject matter Social Science- Elementary school. Therefore, in the development learning materials will be integrated with some of the cultural values of the relevant premises. Some relevant local cultural values (Katoba) to the Social ScienceElementary school curriculum are the social values, culture, economics, politics/history and art/creativity and religion.

Besides, the integration of some sociocultural value in learning katoba Social Science through a cooperative approach with the clarification in terms of the value of learning according to permendiknas 
No. 41/2007-th model is relevant to the theories of learning and the learning model that is selected. Through the development of several stages of Social Science learning model are expected to improve the results of the study (cognitive), strengthen appreciation and attitude of the students towards the local culture (katoba). This emphasis on the learning process through reconstruction, find, acquire knowledge and develop social culture value katoba to believe or understand and serves as a pattern of behaviour guidelines in his social life. The learning process is in line with the emphasis on character education ideals of self-reliance human (moral autonomy) in a neighbourly, community, nation, and State.

Education is not just to build and develop the humanity aspects without bounded by value, but the value of a binder and steering the process of growth and development of personality of learners. Therefore the educational practice should be based on a set of values as a blend between the realm of cognitive, affective, and psychomotor. The reality is less schooling education combines the essential values in the process of learning and more oriented to the development of the cognitive structure only. The character education during this time prefer knowledge of moral, religious or characters ' (transfer of knowledge about religion, morals or character).This implies a social culture which emphasizes education on the character or moral and ethical intellectualism-oriented. In the framework of the humanities study and forming character, it needs the teacher's ability to "touch and greet the overall personal integrity and protégé, includes the feelings, ratio, imagination, creativity and memory.

\section{REFERENCES}

Abdullah, I. (2006). Konstruksi dan Reproduksi Kebudayaan. Yogyakarta:Pustaka Pelajar.

Adimihardja, K. (2008). Dinamika Budaya Lokal. Bandung: CV. Indra Prahasta bersama Pusat Kajian LBPB. Algesindo.

Alma, B. (2010). Pembelajaran Studi Sosial. Bandung: Alfabeta.

Al-Qur'an dan Terjemahannya. (2006). Departemen Agama RI.

Alwasilah, A. C. (2009). Etnopedagogi (Landasan Praktek Pendidikan dan Pendidikan Guru). UPI, Bandung. Ayatrohaedi. (1986). Kepribadian Budaya Bangsa (Local Genius).Jakarta: Pustaka Jaya.

Armstrong, K. (2005). A Short History of Myth. London: Canon Gate Book.

Asmani, M. (2011). Tips Menjadi Guru Inspiratif, dan Inovatif. Yogyakarta: Diva Press.

Badan Standar Nasional Pendidikan, (2011). Standar Kompetensi dan Kompetensi Dasar Sekolah Dasar/ Madrasah Ibtidaiyah. Jakarta: Kementerian Pendidikan Nasional. Banks, J.A. (1985). Teaching Strategies for the Social Studies. New York: Longman

Bandura, A. (1977). Social Learning Theory. Englewood Cliffs, NJ: PrenticeHall.

Bardia, La Ode. (2009). "Kantola di Kabupaten Muna dalam Prespektif Linguistik Kebudayaan”. Denpasar: Tesis Program Magister PPs Unud. Denpasar;Tidak diterbitkan.

Burhanuddin, B., (1987). Dampak Modernisasi dalam Hubungan Kekerabatan di Sulawesi Tenggara. Kendari 
Bunyamin. (2004). Penilaian Terhadap Pelatihan Keterampilan Budaya Para Siswa. Tesis Pada Program Magister, Progam Studi Kajian Budaya, PPS. Universitas Udayana. Bali.

Borg, W. R. and M. D. Gall. (1989). EducationalResearch:AnIntroduction. Fifth Edition. New York and London: Longman

Bruce Joyce, Marsha Weil,Emily Calhoun. (2011). Models of Teaching (ModelModel Pengajaran). Pustaka Pelajar: Yogyakarta.

Charles R. Kniker. (1977).You and Value Education. Charles Merrill.

Crow \& Crow. (1973). Educational Psychology. New York: Little Field Adam.

Couvreur. (2001). Katoba Sebagai Model Pendidikan Karakter Berbasis Kearifan Lokal.LPPM. Universitas Haluoleo Kendari.

Couvreur, J. (Rene Van den Berg, editor), (2001). Sejarah dan Kebudayaan Muna. Arta Wacana Press Kupang.

De Porter, Bobbi dkk. (2007). "Quantum Teaching." Bandung: Yayasan Kaifa.

Dewey, J. (1974). The Child and The Curriculum,and The School and Society. Chicago and London: The University of Chicago Press.

Faridl, M. (1999). Pokok-Pokok Ajaran Islam. Bandung: Pustaka.

Fardus. (2009)."Model Pendidikan Nilai Sosial Budaya dalam Keluarga dan Lingkungan Manusia Bajo di Bajoe." Bandung: Disertasi Prodi PLS SPs UPI.

Farisi, M. (2005). Rekonstruksi Dasardasar Pemikiran Pendidikan IPS-SD Berdasarkan Perspektif Konstruktivisme.(Disertasi): Bandung: UPI.
Gagne, R.M. (1977). The Conditions of Learning. Edisi III. New York: Holt, Rinehart, and Winston.

Gardner. (2004). How Education Changes: Considerations of History, Science, and Values, (Edited). Marcelo M. Suarez-Orozco and Disiree Baolian, Qin-Hilliar

Hadirman. (2009). "Fungsi Sosial Budaya Bahasa Muna dalam Konteks Katoba”. Tesis Program PPs Unud. Denpasar: Tidak diterbitkan.

Hardin.(2010).TradisiLisan RitualKatoba (Tlrk) Sebagai Produk Dan Praktek Budaya Islam Yang Mencerminkan Seperangkat Norma Dan Nilai Sosial Budaya Bagi Masyarakat Etnik Muna, Thesis. Pps. Universitas Udayana Bali

Harvey, D. (1996). The Condition of Postmodernity. Cambridge: MA\& London, UK: Blackwell.

Hergenhahn B.R, Matthew H. Olson. (2012). Theories of Learning (Teori Belajar). Jakarta: Kencana Prenada Media Group.

Herimanto, W. (2008). Ilmu Sosial \& Budaya Dasar. Jakarta: Bumi Aksara.

Insawan, H. (2011). Katoba Sebagai Model Pendidikan Karakter BerbasisKearifan Budaya Lokal(Studi Tentang Ritual Budaya Lokal pada Masyarakat di Kabupaten Muna Provinsi Sulawesi Tenggara untuk Pengembangan Pendidikan Karakter pada Anak Sekolah). Balitbang Depag, Jakarta.

Judistira K. Garna. (1987). Perubahan

Sosial Budaya (Masyarakat Baduy), Unpad: Bandung.

Joyce, Bruce \& Marsha Weil. (2011). Models of Teching (Model-Model Pengajaran), Yogyakarta, Pustaka Pelajar. 
J. Couvreur. Rene van den Berg.(ed.). (2001). Sejarah dan Kebudayaan Kerajaan Muna. Artha Wacana Press: Kupang.

Kluckhohn.C. (1962). Values and Values Orientation In The Theory Of Action. Dalam Parson.et.al (ed). Toward A General Theory of Action. New York: Harper \& Row.

Kimi Batoa. La. (1991). Sejarah Kerajaan Daerah Muna. Astri: Raha-Muna

Kusmahidaya. Y. (2010). Agama Dalam Transformasi Budaya Nusantara. Bandung: Bintang Wali Atika.

Kniker. C.R.. (1977). You and Value Education. Colombus. Ohio: Charles E. Merril Publishing Company.

Koentjaraningrat.(1984).Kebudayaan Mentalitas dan Pembangunan. Cetakan ke-11. Jakarta: Gramedia.

La Fariki. (2010). Tradisi Katoba Dalam Masyarakat Muna. Depdikbud.Bidang Kebudayaan. Raha: Muna.

La Kadir. dkk. (2011). Nilai-Nilai Budaya dan Sejarah Daerah Kabupaten Muna. Diknasbud.

Lundgren.L. (1994). Cooperative Learning in The Science Classroom. GLENCOE Macmillan/McGraw-Hill.

Maftuh. B. (2009). Bunga Rampai Pewarisan Nilai. Bandung : Prodi Pendidikan Umum/Nilai. SPS. UPI.

Malik. Muh. Lutfi. (1997). Islam dalam Budaya Muna; Suatu Ikhtiar Menatap Masa Depan.Ujung Pandang: Uniform Ukhuwah Grafika.

Maslow.A.H. (1970). Motivation and Personality. New York: Harper and Row Publisher.
Max Weber. (1990). Etika Protestant dan Spirit Kapitalisme: Sejarah Kemunculan/PPL. Pustaka Pelajar. Yogyakarta.

Mutakin, A. Rahmat Cece. (2008). Hakekat manusia dalam Dinamika Sosial Budaya. Bandung. Universitas Pendidikan Indonesia.

Moleong. Lexy J. (2004). Metodologi Penelitian Kualitatif; Edisi Revisi. Bandung : PT Remaja Rosdakarya.

NCSS.(2000). National Standards for Social Studies Teachers: National Standards for Social Studies Teaching . Vol. 1. Washington. DC: NCSS.

Oba La. (2005). Muna Dalam Lintasan Sejarah. Rosda Karya. bandung

Olim.A. (2007). Teori Antropologi Pendidikan. 'Ilmu dan Aplikasi Pendidikan. Bandung. Pedagogiana Press;

Oliva. P.F. (1988). Developing the Curriculum. Edisi II. Boston: Scott. Foresman and Company.

Pai. Y. (1970). Cultural Foundation of Education. New York: Macmillan. Publishing Company.

Parson. T. (1992). Essays in Siciological Theory. New York: Light and Live Publisher.

Piliang, Y. A. (2005). "Menciptakan Keunggulan Lokal untuk Merebut Peluang Global: Sebuah Pendekatan Kultural". Makalah disampaikandalam Seminar Membedah Keunggulan Lokal dalam Konteks Globaldiselenggaran oleh ISI Denpasar. 26 Juli 2005.

Rauf La Ode Abdul. (1987). Peranan Elit Dalam Proses Modernisasi (Suatu Studi Kasus di Muna Sulawesi Tenggara). Disertasi. Unhas 
Ranjabar. Jacobus. (2008). Sistem Sosial Budaya Indonesia Suatu Pengantar. Bogor: Ghalia Indonesia.

Richard I. Arends, (2008). Learning to Teach (Belajar untuk mengajar). Yogyakarta: Pustaka Pelajar.

Rusman. (2012). Model-Model Pembelajaran, Mengembangkan Profesionalisme Guru. Jakarta: Rajawali Press.

Robinson, Kathryn \& Mukhlis Paeni. (2005). Tapak-Tapak Waktu Kebudayaan, Sejarah, dan Kehidupan Sosial di Sulawesi Selatan. Makassar: Inninnawa.

Rohmayanti, N. (2009). Pengembangan Keterampilan Sosial Berbasis Nilai-Nilai Religius(Studi Kasus Pengembangan Keterampilan Sosial Lingkungan Hidup Islam Pada Pondok Pesantren Al-Ithifag).(Disertasi). Bandung: UPI.

Sadulloh, U. (2008). Pengantar Filsafat Pendidikan. Bandung: Alfabeta.

Sapriya. (2000). Studi Sosial: Konsep dan Model Pembelajaran. Bandung: Rimdi Press.

Sardjiyo, dkk. (2007). Pendidikan IPS di $S D$. Jakarta: Universitas Terbuka Sartini, (2004). "Menggali Kearifan Lokal Nusantara Sebuah Kajian Filsafati." dalam Jurnal Filsafat, Agustus, Jilid 37, Nomor 2

Smith, P. (2001). Cultural Theory: An Introduction. Oxford \& Massachusetts: Blackwell Publishers.

Silvester, P. T. dkk, (2009). Kajian IPS SD. Jakarta: Depdiknas.

Spradley, James P.\& David W. McCurdy (1972). The Cultural Experience. Chicago Science Research Associates.
Spradley, J. P. (1977). Antropology: The Cultural Perspective. New York: Wiley.

Suprayekti. (2004). Pembaharuan Pembelajaran di SD. Jakarta: Pusat PenerbitanUT.

Sutarjo, A. (2012). Pembelajaran Nilai Karakter. Jakarta, PT. Raja Grafindo Persada.

Suwarma, A. M. (2004). Pengembangan Berpikir dan Nilai dalam Pewarisan IPS. Bandung: Mandar Maju.

Trimo. (2007). Pendekatan Penanaman Nilai dalam Pendidikan.[Online]. Tersedia: http://re-searchengines. com/o807trimo.html. [16 Sept 2008]

Undang-Undang Guru dan Dosen, No. 14 Tahun 2005, Depdikbud

Undang-Undang Sistem Pendidikan Nasional No. 20 Tahun 2003. Depdikbud.

UNESCO. (1993). Education For All : Status and Trend., UNESCO.

Uzey. (2009). "Macam-macam Nilai". Dalam http://uzey.blogspot. com/2009/09/

Waruwu, F.E.(2010).Membangun Budaya Berbasis Nilai. Yogyakarta : Kanisius Wuryandani,W. (2010). Integrasi Nilai-Nilai Kearifan Lokal Dalam Pembelajartan Untuk Menanamkan Nasionalisme di Sekolah Dasar. (Online), avaliable in :http://staff.uny. ac.id/sites/default/file/132309077, (26 Desember 2011).

Woods, (2008),Nilai-Nilai Sosial (online), Tersedia: http://id.wikipeda org/wiki/ nilai sosial (07-7-2008). 
LAODE MONTO BAUTO,

Socio-Cultural Values as Community Local Wisdom Katoba Muna in the Development of Social Studies

Learning Materials for Elementary School

Yadi, Y. (2010). Tradisi Budaya Lokal Dalam Membentuk Karakter Anak Melalui " Model Pendidikan Karakter Pada Masyarakat Adat Kampung Benda Kerap Cirebon".Disertsi PLS, SPS. UPI Bandung.
Zainal,A.(2011).PersinggunganIslamDan Budaya Lokal Dalam Tradisi Katoba Pada Masyarakat Muna Sulawesi Tenggara (Tinjauan AntropologisHistoris). Balitbang Depag. Zamroni.(1999). Pengantar Pengembangan Teori Sosial. Yogyakarta: TiaraWacana. 